\title{
How Parents and Agents Can Address Bullying with Youth1
}

\section{Rosemary V. Barnett ${ }^{2}$}

Recently the American Medical Association (AMA) adopted a new anti-bullying policy that concluded that bullying is not just another childhood behavior that will eventually be outgrown, but rather a public health problem that can have long-term effects for both the bully and the victim. Children who don't escape the cycle of bullying are at higher risk for serious academic, social, emotional, and legal problems. This has been reinforced by a report from the AMA indicating that $7-15 \%$ of school-aged children are bullies and one in 10 school children is a victim of bullying (Peck, 2002).

Research has shown that bullying seems to increase through the elementary years, peak in the middle school/junior high school years, and decline during the high school years (Batsche \& Knoff, 1994). School size, racial composition, and school setting have not been found to be distinguishing factors in predicting bullying (Olweus, 1993). Physical aggression has been found to decrease with age, yet verbal aggression appears constant (Nolin, Davies \& Chandler, 1995). Boys typically engage in and are victims of bullies more frequently than girls (Whitney \& Smith, 1993).

\section{What is bullying?}

While bullying is typically thought of as those direct behaviors, including teasing, threatening, taunting, and hitting by one or more students against a victim, it may also be an indirect attack causing social isolation through intentional exclusion (Banks, 1997). A recent New York Times story on "relational aggression"-when bullying involves tactics that lead to isolation or stigmatizing of other children-expands the typical perception of bullying from aggression and physical violence, into other domains of youth development that have a different set of potential consequences. Indeed, manipulating a behind-the-back rumor scenario that causes another to be shunned by his or her peers was not included in the typical stimulus-response pattern previously addressed by those in the field, especially those new scenarios now being orchestrated by youth through the use of computer technology including Web sites, e-mails, and chat rooms.

Adding to the problem are perceptions of bullying, often held by students who feel that victims are at least partially responsible for bringing bullying on themselves and that bullying toughens a weak

1. This document is FCS2243, one of a series of the Family, Youth and Community Sciences Department, Florida Cooperative Extension Service, Institute of Food and Agricultural Sciences, University of Florida. Original publication date: December 2005. Visit the EDIS Web Site at http://edis.ifas.ufl.edu

2. Rosemary V. Barnett, asstistant professor, Deptarment of Family, Youth and Community Sciences, Cooperative Extension, Institute of Food and Agricultural Sciences, University of Florida, Gainesville, FL 32611.

The Institute of Food and Agricultural Sciences (IFAS) is an Equal Opportunity Institution authorized to provide research, educational information and other services only to individuals and institutions that function with non-discrimination with respect to race, creed, color, religion, age, disability, sex, sexual orientation, marital status, national origin, political opinions or affiliations. U.S. Department of Agriculture, Cooperative Extension Service, University of Florida, IFAS, Florida A. \& M. University Cooperative Extension Program, and Boards of County Commissioners Cooperating. Larry Arrington, Dean 
person (Oliver, Hoover \& Hazler, 1994). Parents are often unaware of a bullying problem and consequently do not talk with their children about it (Olweus, 1993). Students often feel that adults are ineffective and infrequent in their interventions, and that teachers seldom or never talk to them about bullying in their classes (Charach, Pepler, \& Zeigler, 1995).

\section{What can be done?}

Many intervention programs are reframing the way they address bullying. Some programs focus on the resolution of conflict (Barnett, Adler, Easton \& Howard, 2001) while others try to involve the entire school community including bystanders, not just the bully and victim (Slaby, Wilson-Brewer \& Dash, 1994). Yet there are certainly some steps that extension agents, parents, and educators can take together to encourage involvement in creating a safe and fear-free learning environment.

\section{Discuss the expanded definition of bullying} so that parents and youth understand what now constitutes bullying. For example, bullying can now occur in electronic media such as e-mail, blogs, and instant messaging.

\section{Encourage parents and youth to become} more open-minded, tolerant, and accepting. Help them to see things from other perspectives with an understanding of different cultures, values, and norms.

\section{Encourage children to report bullying, even} when they are afraid to do so. Teach them that it is only when the silence is broken that the real work may begin.

4. Build conflict resolution skills by providing demonstrations of how to use steps provided by some model programs proven to be effective. Provide leadership that demonstrates how to manage conflict in ways that helps youth grow, continuously learn, and become better citizens.

\section{Listen carefully and encourage the listening} skills of others. Allow and encourage an open dialogue that shows how to get everyone's point of view out in the open.
6. Brainstorm solutions to the conflict and consider how each alternative solution may prompt a different outcome.

7. Discuss the proper use of technology in the home and at school. Encourage parents, students, and educators to use home and school computers for productive use, discourage destructive internet chatting and instruct parents on the careful and sporadic monitoring of Internet searches and Web sites created by youth.

8. Consider involving your pediatrician when physiological and/or psychological symptoms appear and are unexplained.

9. Build supportive home environments that allow families to discuss problems together and learn how to deal with frustration, stress, and anger.

10. Stay involved in local schools and activities for youth. Build on positive assets and protective factors for the individual, youth, and community.

\section{References}

Banks, R. (1997). Bullying in Schools. On-line at:

http://www.eric.ed.gov/ERICDocs/data/ericdocs2/ content_storage_01/0000000b/80/2a/28/60.pdf

Barnett, R.V., Adler, A., Easton, J.O., \& Howard, K.P. (2001). An evaluation of Peace Education Foundations Conflict Resolution and Peer Mediation Program. School Business Affairs, Volume 67, Number 7, pp. July 2001.

Batsche, G.M., \& Knoff, H.M.(1994). Bullies and their victims: Understanding a pervasive problem in the schools. School Psychology Review, 23(2), 165-174.

Charach, A., Pepler, D., \& Zeigler, S. (1995). Bullying at school—a Canadian perspective: A survey of problems and suggestions for intervention. Education Canada, 35(1), 12-18.

Nolin, M.J., Davies, E., \& Chandler, K. (1995). Student Victimization at school. National Center for Educational Statistics. Statistics in Brief (NCES 95-204). 
Oliver, R., Hoover, J.H., \& Hazler, R. (1994).

The perceived roles of bullying in small-town

Midwestern schools. Journal of Counseling and

Development, 72(4), 416-419.

Olweus, D. (1993). Bullying at school: What we know and what we can do. Cambridge, MA:

Blackwell.

Peck, P. (2002). School Bullying Widespread. Internet: WebMD. Online at:

[http://content.health.msn.com/content/article/ 2606.2001).

Slaby, R.G., Wilson-Brewer, R., \& Dash, K. (1994). Aggressors, Victims, and Bystanders: Thinking and Acting to Prevent Violence. Newton, MA: Education Development Center, Inc.

Whitney, I., \& Smith, P.K. (1993). A survey of the nature and extent of bullying in junior/middle and secondary schools. Educational Research, 35(1), 3-25. 